\title{
КУЛЬТУРНА ТЕМАТИКА В ЕФIPI FRANCE 24: УРОКИ ДЛЯ УКРАЇНИ
}

\author{
Людмила Федорчук ${ }^{1}$ \\ Наталія Пушкарук \\ Інститут журналістики, \\ Київський національний університет імені Тараса Шевченка, \\ вул. Юрія Іллєнка, 36/1, 04119, Київ, Украӥна \\ e-mail:lfedorchuk@ukr.net, nataliiainform@gmail.com \\ ${ }^{1}$ https://orcid.org/0000-0001-6485-9496
}

Стаття присвячена дослідженню особливостей висвітлення культурної тематики в програмах телеканалу іномовлення Франції - France 24. Представлено структуру іномовлення Франції, проаналізовано програмне наповнення телеканалу та проведено моніторинг циклових телепрограм культурної тематики. У результаті дослідження з'ясовано, що структура та формати французьких передач відповідної тематики є різноманітними та насиченими. Автори пропонують конкретні рекомендації щодо висвітлення культурної тематики в ефірі телеканалу іномовлення України UA|TV. $\mathrm{UA} \mid \mathrm{TV}$

Ключові слова: іномовлення, культура, телебачення, Україна, Франція, France 24,

Постановка проблеми. Культура - інструмент, що іноді здатен вплинути на людей ефективніше за політичні гасла та пропаганду, тому іномовні канали інших країн світу, в т. ч. Франції, добре це розуміючи, звертають особливу увагу на передачі культурної тематики у сітці свого мовлення. Необхідність цього дослідження пояснюється тим, що Україна в силу об'єктивних причин потребує підтримки світової спільноти. Іномовлення загалом та передачі культурної тематики зокрема можуть значно посилити позитивний образ нашої країни за кордоном, ознайомити з нашою культурою, традиціями, історією.

Природа, історія та структурні особливості іномовлення були об'єктом досліджень О. Мелещенка [1], М. Малого [2], О. Джолоса [3], В. Набруска [4], О. Гресько [5], В. Конах [6], А. Кострубіцької [7], А. Юричка [8], С. Даниленка [9]. Особливостям міжкультурного діалогу на основі контенту французького телебачення присвятила кандидатське дослідження С. Вернигора [10].

Мета дослідження. Визначення особливостей висвітлення культурної тематики телеканалом іномовлення Франції France 24 шляхом компаративного аналізу програм відповідної тематики. Реалізація цієї мети передбачає розв'язання таких завдань:

(С Федорчук Л., Пушкарук Н., 2019 
- опис структури французького іномовлення;

- моніторинг програм культурної тематики на телеканалі France 24;

- виявлення і опис прийомів використання мультимедійного контенту на сайті та в програмах телеканалу France 24;

- створення рекомендацій щодо адаптування іноземного досвіду та використання його в продуктивній діяльності українського іномовлення.

Джерела дослідження. Передачі «La Paris des Arts», «À l'affiche!», «Vous etes iсi», що виходять на французькому іномовному телеканалі France 24.

Методологія дослідження. В ефірі телеканалу France 24 виходять 34 програми - саме така кількість міститься на сайті в підрозділі «програми». 3-поміж них ми обрали такі, що, відповідно до їхнього змісту, можна вважати культурницькими, та такі, де культурна тематика висвітлюється лише в окремих випусках.

Насамперед це телепрограми «À l'affiche!» (з франц. «На афіші») та «Le Paris des Arts» (з франц. «Париж мистецтв»). По-перше, назви цих передач безпосередньо вказують на те, що вони мають стосунок до культурної тематики. По-друге, з їхнього короткого опису можна дізнатися, що вони висвітлюють теми культури. По-третє, проглянувши анонси до кожної конкретної передачі, ми дійшли висновку, що їхніми гостями чи героями, про діяльність і життя яких розповідається, є особистості, чиї професії, захоплення пов’язані з мистецтвом і культурою.

Серед передач каналу є ще одна, що лише опосередковано стосується предмету нашого дослідження. Тобто серед усіх її випусків лише деякі стосуються культурної тематики, відповідають окресленим вище критеріям. Це передача під назвою «Vous êtez ici» (з фран. - «Ви - тут»).

Дослідження полягало в тому, щоб виявити типову структуру аналізованих передач; дізнатися, на які теми культурної тематики звертається найбільша увага; з'ясувати, яку функцію несуть передачі: освітню чи суто розважальну, які саме знання можуть отримати глядачі з цієї передачі; який образ країни за кордоном формують такі передачі тощо.

3 цією метою були обрані критерії, за допомогою яких був здійснений аналіз. Спільними для всіх передач були такі параметри:

- структура випуску;

- зміст випуску;

- учасники передачі;

- якій культурній темі (темам) присвячений випуск;

- наявність додаткових зображальних засобів у відеоряді (відеоепізодів, фото, зображень, музики тощо);

- хронометраж передачі.

Обираючи, які саме випуски передач досліджувати та за який відтинок часу, ми послуговувалися таким принципом. У програмі «A l'Affiche!» - щоб було рівноцінно охоплено випуски за рік. У програмі «Le Paris des Arts» ми проаналізували випуски передач за три роки і відібрали їх таким чином, щоб вони охоплювали всі місяці року. 3 огляду на те, що випуски програми «Vous etes ici» присвячені дуже різним темам, ми обрали серед них лише ті, що присвячені культурній тематиці й були опубліковані протягом листопада 2017-листопада 2018 року.

Результати дослідження. 1. Іномовлення Франції здійснюється медіа, які входять до холдингової компанії France Médias Monde [11]: телеканалом France24, раді- 
останціями Radio France Internationale (RFI) і Monte Carlo Doualiya. Телеканал France 24 здійснює мовлення чотирма мовами: французькою, англійською, іспанською та арабською. Найбільшою кількістю мов - п’ятнадцятьма - доступна радіостанція RFI. A радіo Monte Carlo Doualiya мовить лише арабською мовою і охоплює аудиторію країн Близького Сходу, Мавританії, Джибуті, Південного Судану.

2. Програма «Le Paris des Arts» [12]. Ведуча - Валері Файоль. У архіві на сайті каналу перший випуск «Le Paris des Arts» датується 23 грудня 2013 року. Програма виходить в ефір по сьогодні. Регулярність - 1-2 передачі щомісяця. Хронометраж приблизно 17 хвилин. За три роки (2016-2018) з 54 передач у вибірку дослідження потрапили 12.

Зі здійсненого дослідження можемо зробити висновок, що кожен випуск програми «Le Paris des Arts» на телеканалі французького іномовлення France 24, не враховуючи рідкісних винятків, має типову структуру. Програма розпочинається з короткої розмови ведучої та запрошеного нею гостя щодо місця, в якому вони перебувають. При цьому спершу глядач не знає, хто саме $\epsilon$ гостем передачі, адже, по-перше, зазвичай його/іï обличчя не показують, а по-друге, на екрані немає титрів 3 іменем людини. Лише після бесіди протягом приблизно 2 хвилин ведуча Валері Файоль представляє співбесідника, його/її професію, посаду тощо та кількома словами анонсує, яких тем стосуватиметься інтервю. Перший блок передачі - це візит Валері Файоль і героя передачі до котроїсь із культурних установ (музею, галереї, театру тощо). Другий блок - інтерв’ю з гостем випуску. Третій блок - герой передачі знайомить глядачів із ще однією людиною, чиє життя та професія пов'язані з культурою, мистецтвом. У більшості випадків передачу завершує бліц-опитування.

Було помічено, що структура випусків, які вийшли в ефір за останніх три роки, залишалася майже незмінною. Лише в останніх двох проаналізованих нами випусках був відсутній блок бліц-опитування, також його не було у випуску «Le Paris des Arts à Carcassone» у зв'язку з великою кількістю учасників. Крім того, у перших випусках передачі питання бліц-опитування були заздалегідь визначені творчою командою передачі, в той час, як в останніх - їх обирали з числа тих, що ставили глядачі за допомогою соцмережі Twitter.

В проаналізованих нами випусках найчастіше обговорювалися теми театру (18\% усіх тем), кінематографу (16\%), музики (15\%). Героями передач найчастіше ставали особистості, пов'язані з музикою (36\% запрошених), театром і кіно (28\%), мистецтвом танцю (15\%).

Великою є кількість додаткових зображальних матеріалів у випуску: під час інтерв'ю на екрані демонструються відеоуривки з фільмів, театральних вистав, зображення кіно та театральних афіш, фото осіб, про яких іде мова.

Було також встановлено, що більшість (64\%) із досліджуваних нами передач були відзняті в Парижі, а решта 36\% - в інших містах Франції та інших країн світу Марселі, Гваделупі, Каркасоні, Марракеші (Марокко), Тель-Авіві (Ізраїль), єревані (Вірменія).

Програма культурної тематики «Le Paris des Arts» на французькому телеканалі іномовлення France 24 виконує не лише культурну, а й освітню функцію, адже знайомить глядачів з усього світу з французькими культурними та освітніми установами, великою кількістю відомих і талановитих особистостей, життям і творчістю істо- 
ричних персонажів, стилями та напрямами мистецтва, відомими творами мистецтва тощо.

3. Програма «A l’Affiche!» [13]. Троє постійних ведучих: Луїз Дюпон, Венсан Ру, Амобе Мевегуе та кілька змінних (Аксель Сімон, Соня Патрічеллі). Програма виходить 3 понеділка по п’ятницю. Хронометраж - приблизно 11 хв.

Кожна передача «À l'affiche!» на телеканалі французького іномовлення France 24 розпочинається з анонсу. Проте випуски відрізняються за форматами. Проаналізувавши 12 передач (по одній передачі на місяць протягом останнього року (з листопада 2017 по жовтень 2018 року), ми дійшли до висновку, що найбільш популярним форматом, за яким відбулися 42\% випусків програми, є інтерв’ю у студії. Менш популярним є новинний формат, у якому поєднується робота ведучого в кадрі у студії та репортажі з місця подій чи сюжети. Така ж частка випусків (25\%) відбулася у форматі позастудійного інтерв’ю. І лише один випуск відбувся в форматі інтерв'ю у студії в поєднанні з сюжетами на іншу тематику.

За тематикою перші три позиції посіли кінематограф (35\% усіх тем), музика (29\%), театр (12\%). Найчастіше в передачі брали участь люди, пов'язані з театром і кіно, музикою, літературою.

Було помічено, що під час передачі глядачам демонструється велика кількість відеоматеріалів, фото та зображень, що спрощує сприйняття інформації.

4. Програма «Vous etes ici» [14] - коротка подорож - знайомство з французькою спадщиною, наприклад, відомими містами, пам'ятками, ремеслами або майстрами своєї справи. Типовий випуск програми «Vous etes ici» - це короткий відеоматеріал без ведучого у кадрі. Періодичність - раз на тиждень. Хронометраж - 5-6 хвилин.

У вибірку дослідження потрапили лише ті випуски, що стосувалися культурної тематики, та з'явилися в архіві на сайті протягом 2017-2018 років. Таких передач виявилося 8. Всі вони присвячені унікальним культурним явищам, закладам чи подіям. Так було встановлено, що найбільша кількість передач (37\%) була присвячена закладам культури: опері Гарньє в Парижі, кабаре Пале-Рояль і Мулен-Руж. Друге місце (по 25\%) розділяють теми, присвячені культурно-освітнім закладам (музей Лувр, Національна бібліотека Франції) та випуски, присвячені музичному мистецтву (співочій спадщині Країни Басків і дзвонарському мистецтву півночі Франції). Лише один випуск був присвячений огляду релігійного мистецтва Савойї (13\% від загальної кількості тем). Було помічено, що у випусках є велика кількість коментарів експертів (67\%), вражень пересічних людей (33\%). Порівняно 3 передачами «Le Paris des Arts» i «À l'affiche!», у випусках передачі «Vous etes ici» демонструється менша кількість фрагментів відео, фото та інших зображень.

5. Французький телеканал іномовлення France 24 приділяє значну увагу застосуванню мультимедійних технологій, виділяючи для них окремі рубрики на сайті [15]. Крім того, дуже далекоглядною стратегією французького іномовлення виявилося те, що воно звертається також до освітнього аспекту, пропагуючи таким чином вивчення французької мови в інших країнах світу, що означає підтримання іiі позитивного іміджу за кордоном. Зокрема, популярними є такі типи подачі інформації $з$ застосуванням інформаційних технологій: інфографіка, веб-документар, карти, хронології, слайд-шоу і звукові слайд-шоу, інтерактивні репортажі.

6. У ефірі українського телеканалу іномовлення UA|TV мають з'явитися нові телепрограми культурної тематики. Це пояснюється тим, що на сайті цього ЗМІ [16] 
немає оновлення від 2017 року ні програми «Ніч у музеї», ні нових випусків програми «Про ART». Крім того, незначною є кількість переглядів цих програм на відео порталі You Tube. Ще одна причина полягає в тому, що програми «Ніч у музеї» та «Про ART» не висвітлюють велику кількість культурних тем і новин, натомість зосереджені на детальному огляді однієї події чи теми.

Телеканалу українського іномовлення UA|TV також варто більшою мірою впроваджувати мультимедійні технології у програмах ефіру та в окремих матеріалах на сайті. Досвід французького іномовлення засвідчив, що така практика - адекватна відповідь на віяння часу, яка, до того ж, дуже допомагає урізноманітнити, осучаснити матеріали та полегшити їх сприйняття.

Для адаптування іноземного досвіду та використання його в продуктивній діяльності українського іномовлення, ми рекомендуємо:

- розробити чітку структуру нової програми культурної тематики, яка складалась би з певної кількості блоків;

- урізноманітнити передачі за допомогою висвітлення низки різних культурних тем, зробити їх більш динамічними;

- висвітлювати актуальні культурні та мистецькі події в Україні, але не обмежуватися цим і фахово та цікаво розповідати про події світового масштабу;

- зробити передачі більш інтерактивними, долучати до їх створення глядачів (проводити опитування в соціальних мережах щодо питань для героя передачі чи щодо того, кого вони хотіли б бачити в ефірі, про що хотіли б дізнатися тощо);

- передачі культурної тематики мають спонукати іноземців відвідувати Україну, ознайомлюватися з її культурою, мистецтвом, для чого треба зробити акцент на так званій «туристичній складовій», показувати культурну спадщину різних українських міст;

- розповідати в передачах про сучасних українських діячів мистецтва, культури, робити інтерв'ю з ними щодо їхніх творчих здобутків, прем'єр тощо;

- включити в передачі освітній компонент, що допомагав би іноземцям вивчати українську мову, наприклад демонструвати титри українською чи англійською мовою.

Перспективи подальших досліджень. Очікується, що результати дослідження будуть використані для вдосконалення методів висвітлення культурної тематики в передачах телеканалу іномовлення України UA|TV. Подібні дослідження на матеріалі програмного наповнення каналів іномовлення інших країн будуть корисними для оновлення контенту всієї системи іномовлення України.

\section{REFERENCES}

1. Мелещенко О. К. Комп’ютерні і телекомунікаційні технології як гарант інтеграції журналістики України в світовий інформаційний простір: Монографія / Київ. ун-т ім. Т.Шевченка. К., 1998. 195 с.

2. Малий М. В. Міжнародна інформаційна експансія в контексті суспільних трансформацій // Наукові записки Інституту журналістики : щоквартальний науковий збірник / Київський національний університет імені Тараса Шевченка. Інститут журналістики. Київ, 2010. Т. 41, жовтень - грудень. С. 110-115. 
3. Джолос О. В. Законодавче забезпечення діяльності державного іномовлення України // Наукові записки Інституту журналістики : щоквартальний науковий збірник / Київський національний університет імені Тараса Шевченка. Інститут журналістики. Київ, 2016. Т. 62. Січень - березень. С. 26-32.

4. Набруско В. Аматорство національного масштабу, або Деякі штрихи державної інформаційної політики [Електронний ресурс] // День : щоденна всеукраїнська газета - Режим доступу: https://day.kyiv.ua/uk/article/media/amatorstvo-nacionalnogomasshtabu.

5. Гресько О. В. Іномовлення в системі міжнародних медіакомунцікацій // Актуальні проблеми міжнародних відносин : збірник наукових праць / Київський національний університет імені Тараса Шевченка, Інститут міжнародних відносин. Київ, 2015. Вип. 123 (ч. 2). С. 14-23.

6. Конах В. К. Еволюція іномовлення України в іноземних державах: досвід для України // Актуальні проблеми міжнародних відносин : збірник наукових праць / Київський національний університет імені Тараса Шевченка. Інститут міжнародних відносин. Київ, 2014. Вип. 118 (ч.1). С. 12-24.

7. Кострубіцька А. В. Іномовлення як об'єкт державного регулювання: досвід країн-членів СС для України // Вісник Київського національного університету імені Тараса Шевченка / Київський національний університет імені Тараса Шевченка. Київ, 2015. С. 26-29.

8. Юричко А. В. Інформаційні безпека України: сучасний стан та перспективи мовлення на закордонні країни // Наукові записки Інституту журналістики : щоквартальний науковий збірник / Київський національний університет імені Тараса Шевченка. Інститут журналістики. Київ, 2006. Т. 23. С. 131-138.

9. Даниленко С. І. «Мультимедійна платформа іномовлення України» як інструмент протидії інформаційним зовнішнім впливам / С. І. Даниленко, М. І. Соботюк // Гілея: науковий вісник: збірник наукових праць : історичні науки, філософські науки, політичні науки / Нац. пед. ун-т ім. М.П. Драгоманова ; ВГО Українська акад. наук ; голов. ред. В.М. Вашкевич. Київ 2017. Вип. 120 (№5). С. 245-248.

10. Вернигора С. М. Французьке телебачення в Україні: особливості міжкультурного діалогу : автореф. дис. на здобуття наук. ступеня канд. наук із соціальних комунікацій : спец. 27.00.04 «Теорія та історія журналістики» / Вернигора Світлана Миколаївна; М-во освіти і науки України, Київ нац. ун-т ім. Тараса Шевченка, Інститут журналістики. Київ, 2013. 16 с.

11. France Medias Monde [Електронний pecypc]. Режим доступу : http://www. francemediasmonde.com (08.02.2019). Назва з екрану.

12. Le Paris des Arts [Електронний ресурс]. Режим доступу : https://www.france24. com/fr/emissions/paris-arts (08.02.2019) - Назва з екрану.

13. À l'affiche! [Електронний ресурс]. Режим доступу: https://www.france24.com/fr/ emissions/a-affiche (08.02.2019) - Назва з екрану.

14. Vous etes ici https [Електронний ресурс]. Режим доступу: https://www.france24. com/fr/emissions/vous-etes-ici (08.02.2019) - Назва з екрану.

15. France 24 [Електронний ресурс]. Режим доступу : http:/www.france24.com/fr (08.02.2019) - Назва з екрану.

16. UATV [Електронний ресурс]. Режим доступу : https://uatv.ua/(08.02.2019) - Назва з екрану. 


\title{
CULTURAL THEMES ON THE AIR FRANCE 24: LESSONS FOR UKRAINE
}

\author{
Liudmyla Fedorchuk ${ }^{1}$ \\ Nataliia Pushkaruk \\ Institute of Journalism Taras Shevchenko National University of Kyiv \\ Yuriia Illienka str., 36/1, 04119, Kyiv, Ukraine \\ e-mail: lfedorchuk@ukr.net, nataliiainform@gmail.com \\ ${ }^{1}$ https://orcid.org/0000-0001-6485-9496
}

The purpose of this article is to define what are the particular features of cultural themes coverage in programs of French international broadcaster France 24. In particular, to find out what is the structure of French broadcasting for abroad, to monitor cultural programs, to describe how multimedia content is used at the web site of France 24 and to make recommendations about coverage of cultural topics at Ukrainian foreign broadcaster UA|TV. It is stated that French broadcasting for abroad is represented by France Médias Monde holding company that consists of TV channel France 24, radio broadcasters RFI and Monte Carlo Doualiya. Monitoring of cultural programs demonstrated that they are very diverse, cover a lot of different topics.

There are 34 programs on the air of France 24 TV channel. We chose among them programs which can be considered as cultural according to their content. Also we analyzed programs in which cultural topics are covered only at particular broadcasts.

We analyzed such programs as «Le Paris des Arts», "Á l'Affiche», «Vous etes ici».

These were criteria for analyzing: structure of the broadcast, its content; participants of the broadcast; to what cultural topic (topics) is the broadcast devoted; presence of additional pictorials (video sketches, photos, pictures, music etc.), timing of the broadcast.

Each of three programs has its own typical structure and style of broadcasting. The most popular topics were theatre, cinema and music. The most common genre was interview.

Besides it we found that France 24 channel pay a lot of attention to use of multimedia technologies and to learning of French. These methods of information presentation are popular: infographics, web-documentary, maps, chronologies, slide-show and sound slide-show, interactive reports. Taking into account French experience we recommended Ukrainian foreign broadcasting channel UA|TV to diversify its cultural programs, cover events that happen in Ukraine nowadays and matters of global importance, create new programs, use multimedia technologies at TV-spots and particular materials on web site. This will be adequate reaction to impulses of time. All the more it will help to diversify, modernize materials and facilitate their perception. Results of this research may be used to improve methods of cultural themes coverage at Ukrainian foreign broadcasting channel UA|

$\mathrm{TV}$ and to update content of all system of Ukrainian broadcasting for abroad.

Key words: international broadcasting, culture, TV, Ukraine, France, France 24, UA|TV. 